a
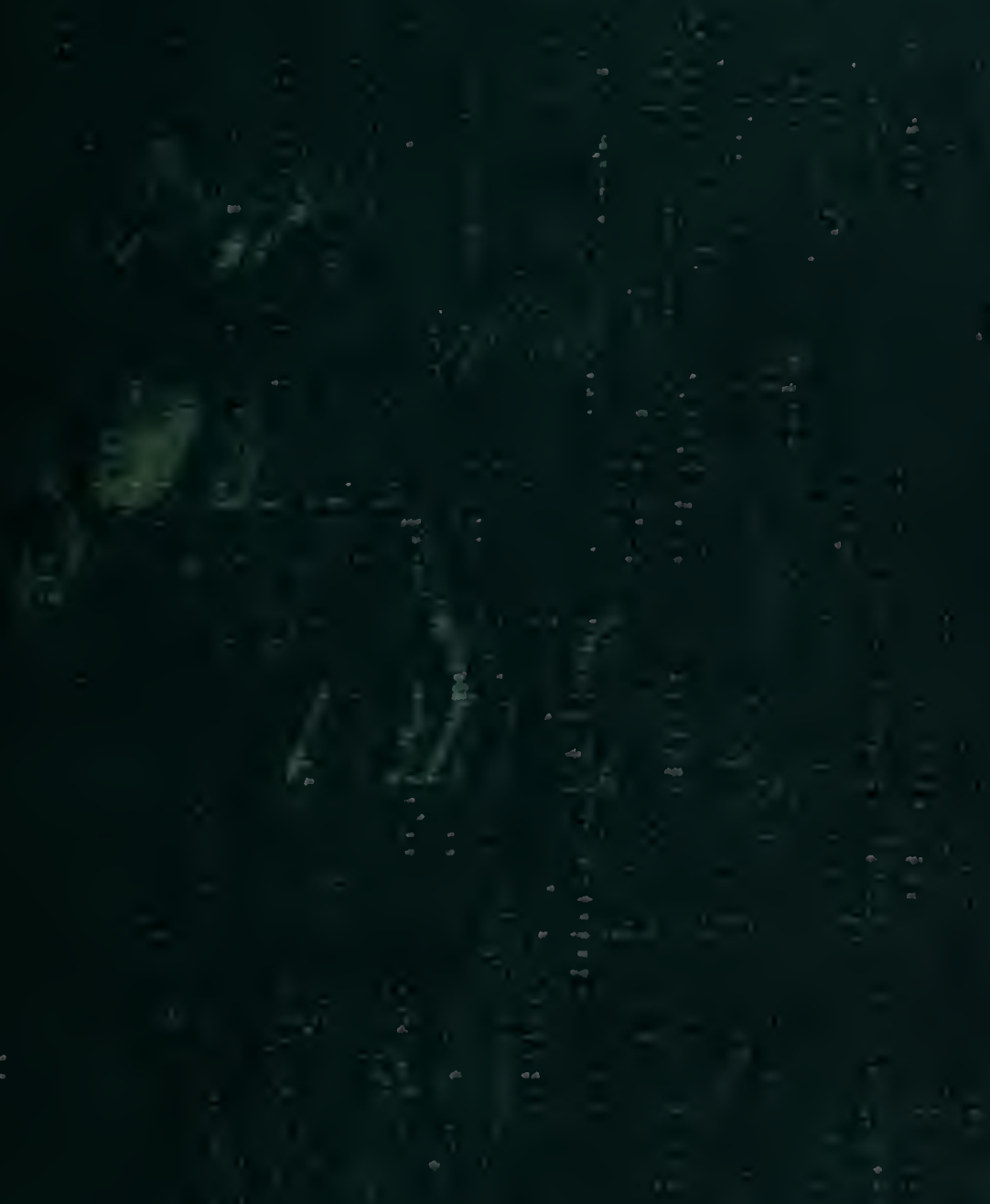


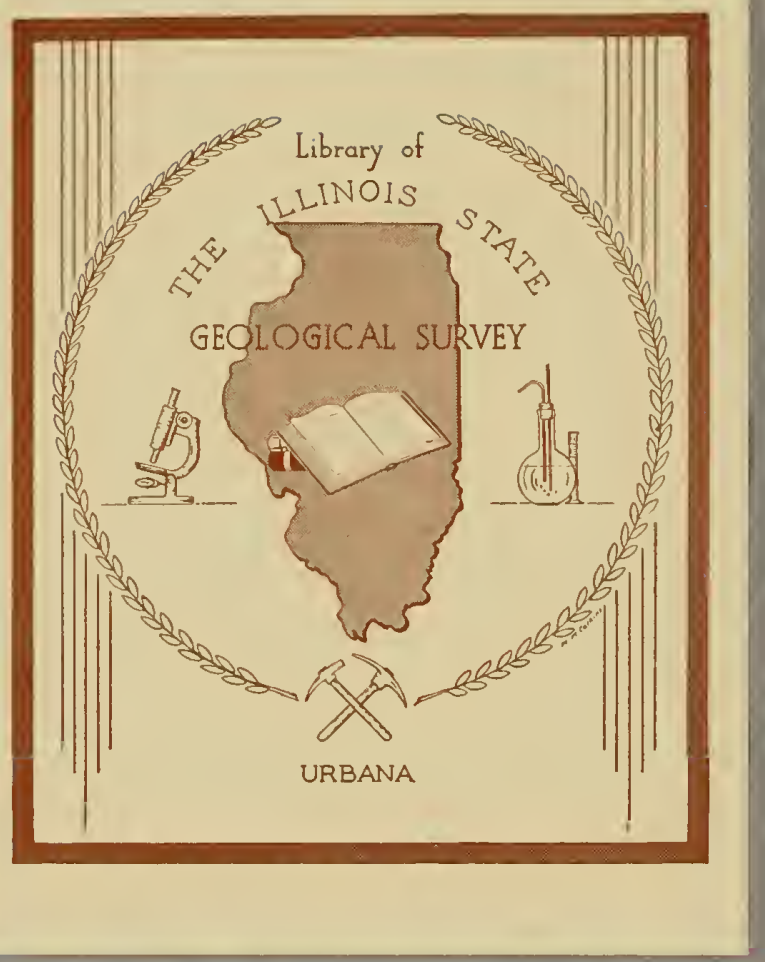




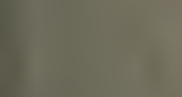

tifli

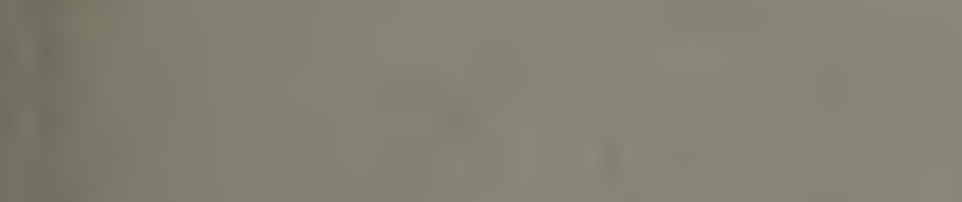

$\sqrt{1}$

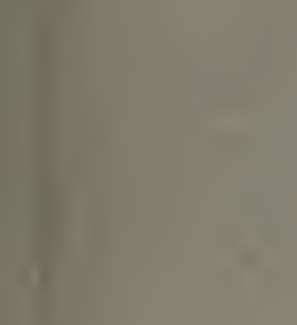

1

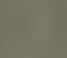
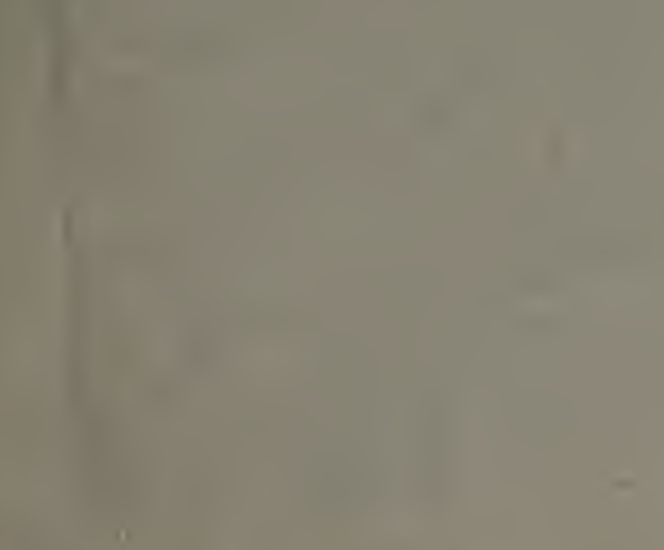

-

\section{$+1$}

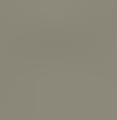




Digitized by the Internet Archive in 2012 with funding from University of Illinois Urbana-Champaign

http://archive.org/details/gastropodgenusyv55718well 
STATE OF ILLINOIS

DEPARTMENT OF REGISTRATION AND EDUCATION

DIVISION OF THE

STATE GEOLOGICAL SURVEY

M. M. LEIGHTON, Chief

REPORT OF INVESTIGATIONS-NO. 18

\section{THE GASTROPOD GENUS YVANIA}

Contribution to the Paleontology of Illinois

BY

J. MARVIN WELLER

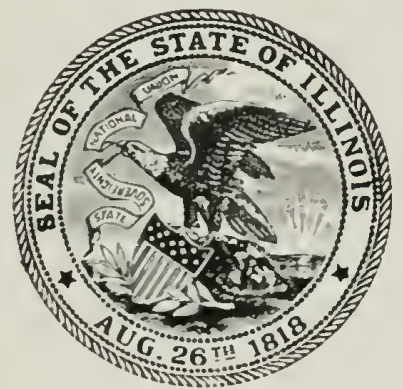

FRINTED BY AUTHORITY OF THE STATE OF ILLINOIS

URBANA, ILLINOIS

1929 
STATE OF ILLINOIS

DEPARTMENT OF REGISTRATION AND EDUCATION

A. M. Shelton, Director

\section{BOARD OF \\ NATURAL RESOURCES AND CONSERVATION}

A. M. Shelton, Chairman

Edson S. Bastin, Geology

IVilliam A. Noyes, Chemistiry

John W. Alvord, Enginecring

William Trelease, Biology
Henry C. Cowles, Botany

Charles M. Thompson, Representing the President of the Unizersity of Illinois

STATE GEOLOGICAL SURVEY DIVISION

M. M. Leighton, Chief

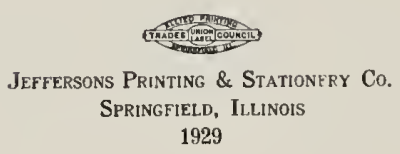

1929 


\section{LETTER OF TRANSMITTAL}

State Geological Survey Division, March 5, 1929

Houl. A. M. Sheltou, Chairman, and Members of the Board of Natural Resources and Conscreation.

Gextlemex:-I take pleasure in transmitting herewith, for publication as Report of Investigations No. 18, the manuscript of the paper entitled "The Gastropod Genus I'auna: Coutribution to the Palcontology' of Illinois," by Dr. J. Marvin Weller. Paleontologist on our Geological Survey Staff.

This is the first of a series of papers which will give the results of our paleontological studies of fossil forms belonging to the Pennsylvanian (Coal Measures) system of Illinois. As you are aware, these studies are for the purpose of determining the composition. evolution and history of the Pennsylvanian faunas and of ascertaining what fossil forms may be used as horizon markers in correlating isolaterl outcrops of Coal Neasures strata; this in turn is funclamental in determining the coal resources of the State and in working out geologic structures to be tested for commercially valualle accumulations of oil and gas. The genus dealt with in this particular paper belongs to the most characteristic family of gastropocls represented in our Coal Measures strata.

Very sincerely yours,

Morris M. Leigititon, Chicf. 



\section{CONTENTS}

Page

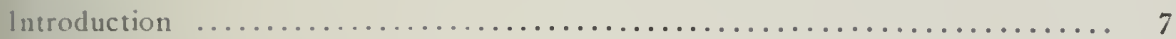

The family Pleurotomariidae.................................... 7

Genus Yrania Bayle (Baylea de Koninck)...................... 8

Genus Yrania Bayle emend. Weller....................... 10

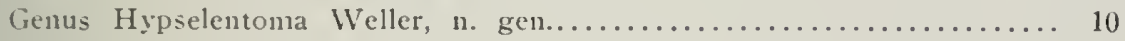

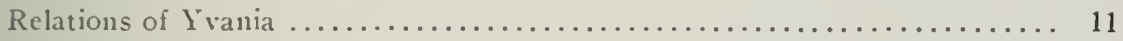

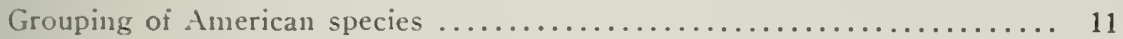

Species tentatively referred to Yvania......................... 12

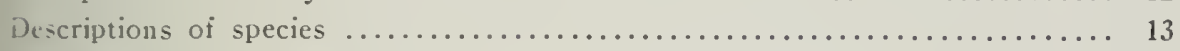

Yvania inclinata Weller, n. sp............................... 15

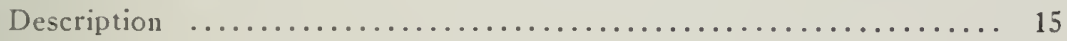

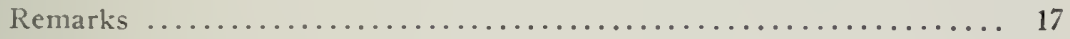

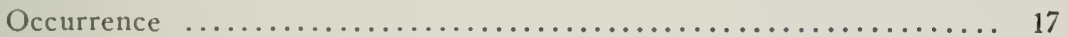

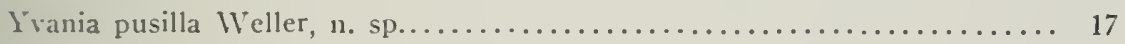

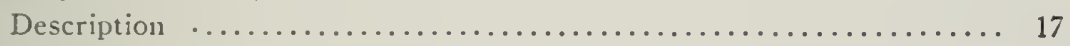

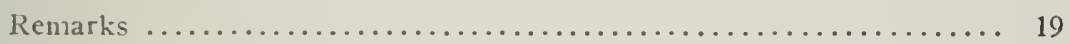

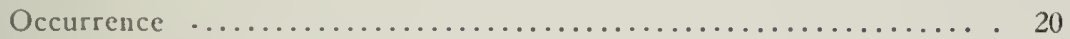

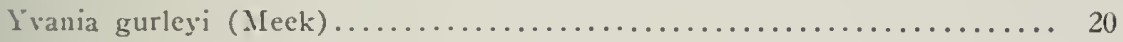

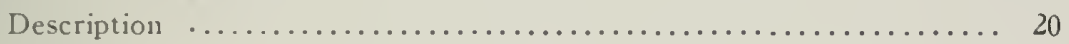

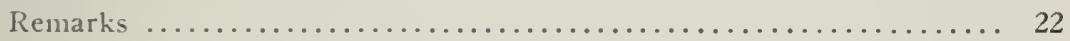

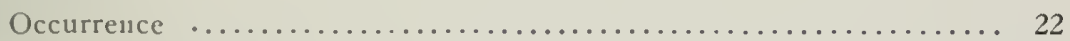

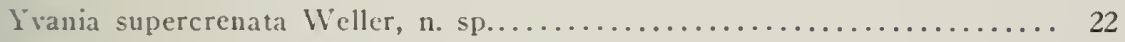

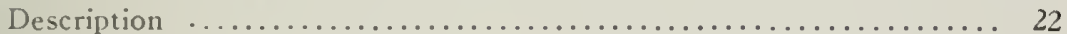

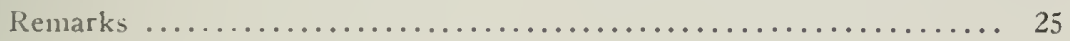

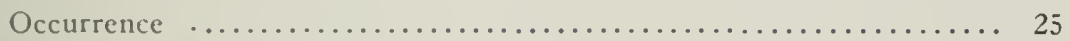

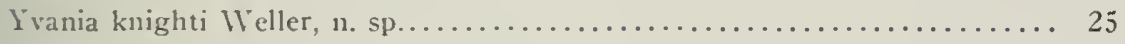

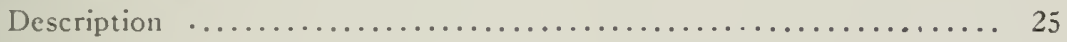

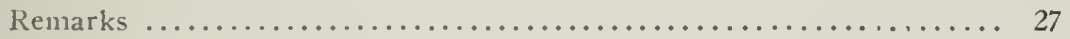

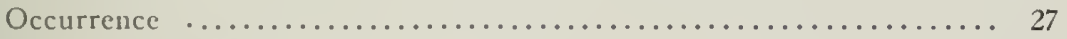

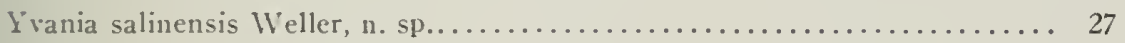

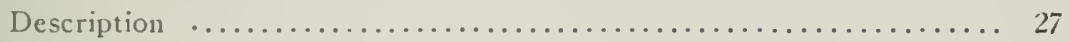

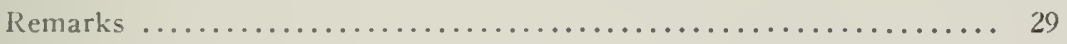

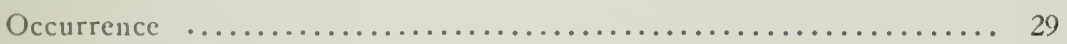

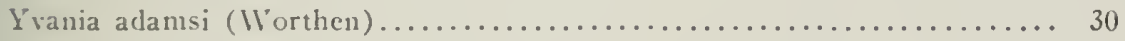

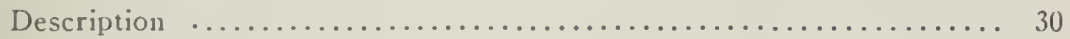

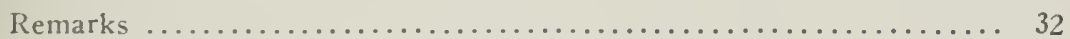

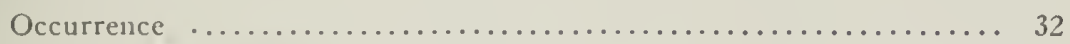

Yvania subconstricta (Mcek and Worthen) ................... 32

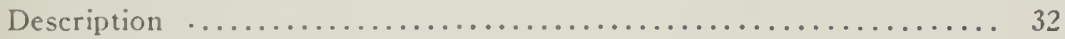

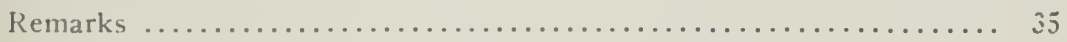

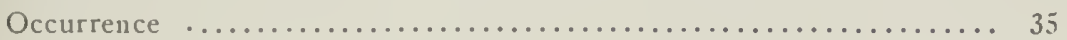


Descriptions of species-concluded

Yvania giffordi (Worthen)

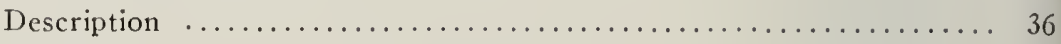

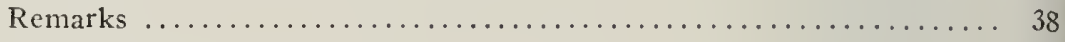

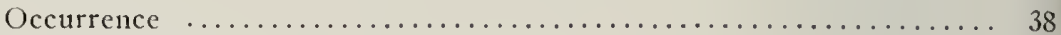

Plates and explanations ................................... 39

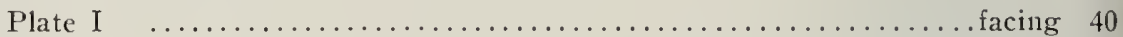

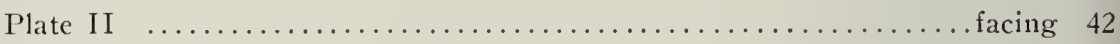

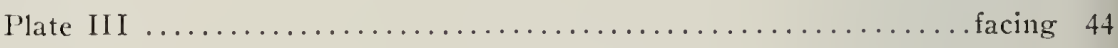




\title{
THE GASTROPOD GENUS YVANIA
}

\section{CONTRIBUTION TO THE PALEONTOLOGY OF ILLINOIS}

\author{
By \\ J. Marvin Weller \\ INTKODUCTION
}

Nodern tendencies in paleontology are toward greater discrimination and finer distinctions between genera as well as between species. It is only in this way that paleontology may leep pace with our more exacting stratigraphic stlidies. This paper on Y'onia is the first of a series that has been planned in which a number of groups of American Carboniferous Pleurotomariidae will be described. It is anticipated that in most cases it will be possible to classify these forms uncler already proposed generic appellations, but it will uncloubtedly: be necessary to redescrile many of the genera in order that their essential characters may be understond and that a grouping more natural and satisfactory than has been accomplished in the past may be made.

\section{THE FAMILY PIEUROT(OMARIIDAE}

The family: Pleurotomariiclae includes a very large number of species occurring in strata which range in age from Cambrian to Recent. The family is characterized loy a spiral shell-halit and a defunitely limited narrow band which terminates in a more or less (leep) sinus of the outer lip) or in a long parallel-sided slit which in some species is closed at intervals.

Within the fanily the species differ in almost every conceivalle detail, so that it has proved a stumbling lolock to many paleontologists who have attempterl to classify its members. The general practice has been to separate a small group as a new grenus or sulgenus. lut differences between the type syecies chosen and other representatives of the family have not always been clearly understookl, and the result has been an unnatural grouping of species. Conservative authors have referred their species either to Plenrotomaria or Wurchisonio accorcling to a single arbitrary character-length of spire. :) thers have compromiserl ly classifying in genera already proposed those yecies which seem to possess correpondling characters and referring the remainder to Pleurotomaria and IIurchisomia. Consequently a large number u. f species whuse rehationships are not sufficiently uncierstond to warrant more precise generic classilication are now included in Plenrotomarin. In this 
respect this genus resembles Aviculopecten among the pelecypods and Productus among the brachiopods, except that the present status of Pleurotomaria is much more unsatisfactory, both on account of the extensive range of its representatives throughout geologic time and because the work which has been done upon its subdivision is less well understood.

The only discussion of the Pfenrotomariiclae in American literature which is at all comprehensive is that by Ulrich in the Paleontology of Minnesota. ${ }^{1}$ He is primarily concerned with lower Paleozoic forms but proposes two new Carboniferous genera and discusses others confined to or represented in these strata. He also lists those characters which in his opinion may be employed in making generic discriminations.

The most extensive consideration of Carboniferous forms is that by de Koninck in his description of the Belgian Carboniferots fauna. ${ }^{2}$ His forms are grouped in eleven genera, most of them new and rather unnatural systematic units as arranged l)y him, which have received almost no recognition from later writers. However, several of these genera are potentially useful; among them is that for which he proposed the name Baylea. It is the purpose of this paper to redefine this particular genus, establish it as a natural unit, and describe the American species that may be referred to it. several of which are new.

\section{Genus YIANIA Bayle (BAYLEA de Koninck)}

In 1883 de Koninck proposed the name Baylea for a group of ten species of Pleurotomariidae, with Baylea l'z'anii Ch. Leveillé as the type. ${ }^{3}$ This name however was preoccupied ly Baylcia Munier-Chalmas 1873, and Yrania, a name proposed in manuscript by Bayle, was substituted by Fischer without emendation in $1885 .{ }^{4}$

A translation of de Koninck's original description of the genus is as follows :

"Shell conical, turreted, spire in form of steps the vertical and horizontal parts of which join each other at a right angle. The band of the sinus, relatively large, is situated on the lowcr (upper) plane part and horizontal to the turns of the spire; it lies along the external angle of these turns and is limited on the opposite side by a fine slightly elevated carina. The upper (lower) part of the last turn is very convex and ornamented with a great number of shallow spiral furrows, which largely occupy the median part. The aperature is large and has the form of an inverted escutchon: its columellar border is thin, and being extended lenthwise, gives rise to the formation of a little umbilical dimple.

1 trlrich E. O. and Scofield. W. H. The Lower Silurian Gastropoda of Minnesola: Geol, and Nat. Hist. Surver of Minnesota, vol, 3, pt. 2, p1). 94f-960, 1897.

2 De Koninck, L, G. Faure de calcaire carlonifire de la litgirue: Annales Mus. Roy, Hist. Nat. Belg., Vol. 8, pt. 4, 1883 .

3 Op cit., p. $6 \delta$

4 Fischer, $F$., Nanuel de Chonchyliologie, 1. S5l, 1885. 
"Dimensions.- The length of the largest specimens rarely exceeds $40 \mathrm{~mm}$. and the 1 rasisierse diameter $25 \mathrm{~mm}$

"Riblations and Lifferences.-The species which I propose to mite in this group) have for principal character the existence of the band of their sinus on the horizontal part and below (above) the thirns of the spire; this band is in consequence invisible When the shell is seen in profile. In the shells of all the other genera of the same family, except on those of the gents Lmiclla in which it is found situated on the upper (lower) part of the turns, it is pertectly perceptible, in this same position, at least on the last turn. No otiue genus posiesses, however, a form so perfectly turreted as that of the group which is here in questien and which has for type Baylea (Pleurotomama) yat tii, Ch. Levcillé.

"Grologic D)istribution.-Nearly all the species of this genus belong in the Car boniferous terrain in which it heconns extinct. In Belgiun two of these species exist in the lower beds of the terrain; two others have been discovered by Mr. Er. Dupont in the miclelle beds, and, finally, two species are found in the upper beels. One species 0 the nuddle beds has been figured in Ireland by Mr. F. McCoy and one other from the upper beds has been lescrihed by: J. Phillips from lorkshire. I have obscrved one or two in the middle beds of the Devonian limestone in the neighborhood of Visé."

Is may lue seen hy the above description, the essential feature upon which this genus is based is the presence of the slit loand on the upper surface and arljacent to the prominent angle of the volution. The turreted form of the spire. which is emplnasizerl ly de Koninck in his generic description, and the neeting of the upuer and outer sicles of the volution at a right angle are by 110 nneans constant characters, and the description is misleading in this respect as may loe seen when the illustrations of de Koninck's ten original species are examined.

Koken" held that this genus was an arbitiary group and pointed to a series connecting the type species, which he considered simply an extreme form of rlevelopment, with species describerl by de Koninck as Ptychomphalus and Yourloniu. When it is considered, however, that these latter genera have no meaning as employed loy de Koninck and served only to hold those species that he could not place elsewhere, Koken's argument loses its significance. Perhaps the species referred to hy him should have been placed originally in the genus Baylea. That de Koninck dir not place them there is without signifcance as hir grouping is in so many respects unnatural.

In the group of species described in this paper the slit hand is located upon the upper slope of the whorl and adjacent to the angle. In five of the sivecies an adclitional feature serves to sharply distinguish them from most other Carloniferous representatives of the Plenrotomariidae, namely a consnicuous backward curvature of the lines of grouth adjacent to the suture. De Koninck's figures of his genotye show that this species also was ornamenterl ly faint growth lines which curved slightly lackward in the vicinity

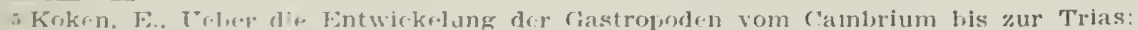
‥ Jahriuch, Plol. 6, p. 32, 185.9. 
of the suture ${ }^{6}$ although this character is nowhere nentioned in his descriptions. Because my Coal Measures species possess these two unusual characters in common with de Koninck's Belgian forms, I confidently place them in the same genus which is here emended as follows:

\section{Genus YVANIA Bayle emend. Weller}

Description.-Pleurotomariidae, medium to fairly high spired, subtrochiform to turreted : mature whorls with one or two sharp lateral angles-if only one angle the whorl has a strongly convex basal portion. Slit band prominent, situated on the upper slope of the whorl just aiove the upper lateral angle, flat or slightly concave, sharply bounded upon each side by raised costae. Aperture, as shown by the lines of growth, convex between the slit and suture. linguliform, extending backward near the suture and meeting it at an angle acute in a backward direction or producing a shallow concave sinus; on the side below the slit band, strongly convex; on the base more or less broadly concave. Columellar lip somewhat thickened and recurved, umbilicus small or closed, no callosity on the inner lip. Surface ornamented by more or less numerous revolving costae which may or may not be raised slightly at intervals to give a nodose appearance, especially adjacent to the suture. Lines of growth faint, rarely observed on some species.

This genus differs from all other angulated Carboniferous Pleurotomariidae in possessing a slit band situated upon the upper slope of the whorl. and by the form of the aperture which extends backward adjacent to the suture.

Genus HYPSELENTOMA Weller, n. gen.

The only other angulated Carboniferous species known to me which possess a band upon the upper slope of the whorl are Plcurotomaria herhumerosa and P. inornata Meek, possibly P. lummerosa Meek and Hayden, and an undescribed form from the Graham formation of Texas. These differ from Yrania in not possessing a true slit, the band being simply the band of the sinus, and also in the forvard direction of the lines of growth as the suture is approached. These forms constitute a well defined and easily distinguished group. It is my desire to establish it as of generic rank, and $\mathrm{J}$ propose for it the name Hypselchtoma and select P. perhumerosa as the type.

6 Op. cit., pl. 27, fig. 5 .

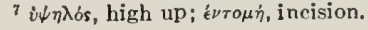




\section{ReLATIONS OF YIH.YI.A}

The genus Ia ania is apparently most nearly related to Gosseletina Bayle (Gossictia de Koninck) as represented by the American Coal Measures species Gosscletina spironima (Meek and Worthen). The species of Yvania lescribed in the following pages. Whose enlyryonic development is known, pats through a stage which is essentially similar to the mature form of Crosscletina in that the slit band is situated well up above the middle of the rounded whorl, and that the lines of growth alıove the hand are more or less linguliform and meet the suture at an angle which is acute in a backward direction. These two groups are probably descended from the same ancestral stock. Of them Gosscletina is the more primitive as it lacks the angulation which is developed in the later whorls in I'ania.

\section{Grotimgig of Aimerican Species}

Nine species of Yrania are described in the following pages. Four of these were described and illustrated by Meek and Worthen in the first series of reports of the Illinois Geological Survey, the remaining five are new. The species of Meek and Morthen have been practically unknown to paleontologists up to this time; the original clescriptions and illustrations are rather inadequate and no later notice of them apjears in paleontologic literature.

The nine species of Yvania described in this paper may be subdivided into four groups as follows:

1. Group of Y'ania gurleyi. These forms are characterized by a somewhat turreterl spire which is ornamented by numerous simple and smooth revolving costae. The upper sloping surface of the whorl is gently concave letween the slit band and a costa which lies upon an angle adjacent to the siture. The form of the aperture leneath the sinus of the band is broadly ancl smoothly curved. The group) also includes $Y$. inclinata and $Y$. pusilla.

2. Group of I'ania supercienatu. This group differs from the prececling principally in that the upper sloping surface of the whorl is flat rather than concave. These two groups are not as closely related as might appear irom superficial examination as the embryonic development is somewhat different. $Y$. knighti is also included in this group).

3. Group of I'z'ania adamsi. This group also contains $Y$. salinensis. These species are conficlently referred to Yania even though growth lines have not been olsservel on any of the specimens exanned and therefore it is not certainly known that the aperture alove the slit band has the shape characteristic of this genus. However exfoliated specimens clearly show that the slit band is lncated upon the upper flattened surface of the whorl and adjacent to the periphery. This character, together with the similar form of the shells 
and the similar type of ornamentation, leaves little doubt as to the reference of these forms to Yvania.

The two species in this group are not as closely similar as those in the other three groups. Nevertheless they possess certain conspicuons common characters, such as the more concave and unornamented lateral surface of the whorl, and the smooth central portion of the basal surface of the whorl occurring between the outer and inner series of spiral costae.

4. Group of Yvania subconstricta. This group which also contains I. giffordi is sharply distinguisher from all of the preceding. In fact the other groups are probably much more closely related to each other than this one is to any of them. The concave form of the upper sloping surface of the whorl is reminiscent of $Y$. gurlcyi and its relatives, but in this group, the slit band is flat and contintes uniformly in the slope of the concave portion of the upper surface of the whorl, whereas in the group of $Y$. gurleyi it is concave and is inclined downward from this slope.

The group of $Y$. subconstricta differs from the others in two important particulars. Growth lines, represented by fine transverse costae, which are prominent on well preserved specimens in the spaces between the revolving ribs, are more conspicuously developed. The transverse costae have not been seen to cross the revolving costae, but the latter are rendered somewhat irregular and lack the smoothness characteristic of the other groups. This is most conspicuous upon the costa at the angle adjacent to the suture, and in some specimens on the next lower one, which are rendered somewhat nodose. A less noticeable character, but probably more significant, is the linguliform outline of the aperture on the lateral slope which is produced by a comparatively sharp concave curvature below. The basal surface of the whorl is also considerably more convex than in any of the precerling groups.

\section{Species Tentatively Referred to $y$ T ANIA}

A search through the literature has failed to reveal a single species from the American Carboniferouts, other than those described in this paper, which may with certainty be includer in the genus Yvania. There are, however. fonr species which should be provisionally placed in this genus on account of certain similarities, lut the descriptions and illustrations of them are inadequate for a precise determination of their relationships. Of these four species, one, Worthomia alamillana Girty, is described from the Upper Pennsylvanian of New Mexico, and the other three, Plurotomaria arenarea Girty, $\dot{P}$. delawarnsis Girty, and $P$. agnostica Beede, are from the Permian of Texas and Oklahoma. No species even suggestive of this genus has heen described from the Mississippian. Apparently Yrania did not appear in America until Pennsylvanian time. 
DESCRIPTIONS OF SPECIES 



\title{
Class GASTROPODA
}

\author{
Order ASPIDOBRANCHIA \\ Family PLELROTOMARIIIAE
}

Genus $Y T / N / A$ Bayle

\section{Yvania inclinata Weller, n. sp.}

Pl. I, fig. 1; P1. II, fig. 9; Pl. III, figs. 2-3b, 6

Description.-Shell small, slightly turreted, spiral angle about $93^{\circ}$; whorls angular, base convex; umbilicus small, partially closed; last whorl forms over half the height of the shell; sturface nurked by numerous revolving costae of various sizes; slit band prominent, concave, inclined slightly to the upper sloping surface of the whorl and adjacent to the angle.

The dinensions of the holotype are: height of entire shell $5.6 \mathrm{~mm}$; height of last whorl 3.t mm. : and width at base $5 .+11 m$. It is composed of about five and a quarter whorls. The first wo turns of the spire are tniformly convex and smooth. The third turn is also convexly rounded but it is omamented by eight fine equally prominent costae, five below and three above the slit band which is outlined by two of them. A much finer costa appears upon the hand itseif. Late in the third whorl the costae bounding the slit band and lowest costa visible below the band become larger and more prominent than the others and the ones above the band also become somewhat more conspicuous than those lelow. In the course of the fourth turn the mature characters of the shell are fully developed as exemplified by the angulation and surface markings.

The mature whorls are subrhonboiclal in outline and are slightly wider than high. The outer surface is clivided into three parts by two angulations the upper of which is sharply localized along the outer borcler of the slit band and forms an angle of ahout $112^{\circ}$, situated below the suture by about one fourth of the height of the whorl. The lower angulation is little more than a regular inward curving of the shell from the flat lateral surface to the convex basal surface of the whorl. The lateral surface makes up a little nore than one third the height of the whorl and slopes shightly outward from a vertical position, as the dianeter of the whorl at the lower angulation is a little greater than at the upper. The basal surface is gently and nearly uniformly convex into the umbilicus.

The whorls are practically non-enloracing, as the spire is formed by each succeeding whorl being attacherl to little more than the basal surface of the preceding one. The suture is narrowly concave and follows the prominent 
costa which marks the beginning of the curvature into the basal surface of the preceding whorl.

The columellar lip is blunt and recurved upon itself but not greatly thickened. It extends over and almost completely hides a very small umbilicus. No thickening or callosity is present upon the inner lip.

The slit band is situated along the outer margin of the upper sloping portion of the whorl and is inclined slightly downward from its general direction. The band is equal in width to slightly less than one fourth of the complete width of the upper surface of the whorl and is bounded by two prominent costae having angular or narrowly rounded crests whose converging slopes give to the band a concave outline. No ornamentation is present upon the surface of the slit band in the mature portion of the shell. Lines of growth are indicated by a few scattered, very faint, crescentic lirae which are slightly asymmetrically curved so that each one touches the outer of the bounding costae at a position a little farther to the rear than that at which it touches the inner.

The two costae which border the slit band are the most prominent markings upon the upper surface of the whorl. A third somewhat less conspicuous costa parallels the suture and is separated from it by a distance about equal to the width of the band. The space between this costa and the hand is slightly concave and is markerl by as many as seven fine thread-like costae, somewhat unequally spaced and in general alternating in size between fine and very fine. A single fine costa occurs midway between the suture and the more prominent costa mentioned above. Lines of growth are well developed upon the upper surface of the whorl and are displayed by slight unevenness of the shell surface. They are linguliform and attain their most advanced position at about the midline of this part of the whorl. They are here regularly convex and sweep backward to join the edge of the band at a sharp angle. Toward the suture the growth lines extend in a sinuous curve, first convex, but as the suture is closely approached the curve becomes slightly concave, and they join the suture in a direction nearly normal to it.

The lateral slope of the whorl below the outer erlge of the slit band is nearly as wide as the upper slope. It is hounded below hy a conspicuous costa which marks the beginning of the curvature into the basal surface. This costa is broad and angular or narrowly rounded, the two slopes leing of about equal intensity. Aloove this costa and separater from it by a distance somewhat less than one third of the width of the lateral surface is another slightly less prominent costa of similar character. Midway between them occurs a third finer costa. The surface between the angle of the whorl and the second costa mentioned above is alout equally divided into two parts. The upper is without revolving narkings and the lower is ormamented by 
three thread-like costae. Growth lines are fairly well shown upon the lateral surface of the whorl. They neet the costa which marks the lower limit of this portion of the shell at right angles and above curve strongly backwarl, approaching the border of the slit band at a very acute angle.

The hasal surface of the whorl is ormamented by numerous revolving custae which are separated from each other by about .15 mm. over the greater part of this surface. On the outer portion, however, they are more widely spaced, the first two being separated from each other and the costa marking the boundary of the lasal surface by distances about equal to that which intervenes between the two most prominent costae of the lateral surface of the whorl. A very fine threat-like costa is present in the outer of these interspaces. The costae of the base apparently do not extend down into the umbilicus. The holotype possesses 15 costae upon its hasal surface. Growth lines are not conspicuous upon the base but where oberved are broadly and shallowly concave over most of this portion of the shell.

Remarks.-The species Yrania inclinata is closely related to $Y$. pusilla and $Y$. gurleyi. The $Y$. pusilla, which is probally a dwarfed form, may be distinguished from $Y$. inclinata not only by its much smaller size but also by its relatively narrower slit band and the outward slope of the lateral surface of its last whorl. The ormamentation of revolving costae is also somewhat more simple. Yrania inclinata may be distinguished from $Y$. gurleyi by its wider slit band bounded ly more prominent costae, by the finer nature of its other markings, and by the thread-like costae adjacent to the suture and upon the lateral surface of the whorl.

Yania inclinata is associated with $Y$. supercrenata from which it may lie differentiated by the concave upper surface of the whorl, the slightly inclined and narrower slit band, the lower spire, the finer and more numerous revolving costae. and the nore uniform spacing of these costae upon the base.

The holotype of this species is No. 19 in the collection of the Illinois State Geological Survey.

Occurrence.-This species occurs in a limestone led which closely underlies the Colchester ( $\mathrm{No}$. 2) coal over large areas in western Illinois. The holotype and a series of other specimens were collected from an outrrop in the northeast bank of Wilson Creek near the southwest corner sec. 26 , T. 3 N., R. 2 E., Fulton County, Illinois.

Yvaxia pisilga Weller, n. sp.

Pl. I, figs. 4a-c

Description.-Shell very small, somewhat wider than high, slightly turteted. spiral angle about $96^{\circ}$ : whorls angular, base convex, umbilicus moderate; last whorl forms over half the height of the shell; surface marked 
by numerous revolving costae; slit band prominent, concave, located on upper sloping surface of whorl and adjacent to the angle.

The dimensions of the holotype which is the largest specimen collected are: height of entire shell $3.3 \mathrm{~mm}$; height of last volution $2.0 \mathrm{~mm}$.; width at base $3.6 \mathrm{~mm}$. This specimen is composed of five whorls. The first three turns are uniformly convex. A number of fine revolving costae are present upon the surface of the third turn but they are so faint that nothing can be said concerning their number or arrangement. At the beginning of the fourth turn there are plainly developed four costae of about equal prominence and nearly equally spaced, the second and third of which bound the area of the slit band. By the end of this turn the whorl has achieved its mature angulation. The slit band has become very little wider than it was at the beginning of this turn but the other costae have spread apart to accommodate themselves to the enlarged surface of the whorl, and a fine thread-like costa has made its appearance in the space just above the slit band. In the course of the fifth and last whorl two more fine costae appear in the space above the slit band and in a similar manner three appear upon the flattened space below it.

The mature whorl is subrhomboidal in outline and about as wide as high. The outer surface is divided into three parts by two angulations the upper of which is sharply localized along the outer border of the slit band and forms an angle of about $125^{\circ}$, situated below the suture by about one fourth the height of the whorl. The lower angulation is not so sharp but consists of an abrupt inward curving of the shell from the nearly flat lateral surface to the convex basal surface of the whorl. The lateral surface makes up a little more than one third the height of the whorl, it is slightly concave and slopes outward from a vertical position inasmuch as the diameter of the whorl at the lower angulation is somewhat greater than at the upper. The curve of the basal surface is gently and nearly uniformly convex until the umbilicus is approached into which it plunges more steeply.

The whorls are practically non-embracing, as the spire is formed by each whorl being attached to little more than the basal surface of the preceding one. The suture is narrowly rounded and occurs at or near the prominent costa which marks the beginning of the curvature into the basal surface of the preceding whorl.

The columellar lip is rather blunt and recurved upon itself but not greatly thickened. It extends over and partially hides the umbilicus. No thickening or callosity is present upon the inner lip.

The slit band is situated along the outer margin of the upper sloping portion of the whorl and is inclined slightly downward from its general direction. The band is equal in width to about one fifth of the complete width of the upper surface of the whorl and is bounded by two prominent costae 
having angular or narrowly rounded crests whose converging slopes give to the band a concave outline. No ornamentation is present upon the slit band. Lines of growth are indicited by very slight unevemness of its surface but their details camnot be made out.

The two costae which border the slit band are the most prominent markings upon the upper sloping surface of the whorl. A third slightly less conspicuous costa parallels the suture and is separated from it by a clistance about equal to the width of the band. The space between this costa and the suture is flat, smooth, and unornamented. The space between the costa and the hand is slightly concave and carries three fine thread-like costa nearly evenly spaced. Growth lines are not apparent upon this part of the shell.

The lateral slope of the whorl below the outer edge of the slit band is about equal in width to the upper surface. It is bounded below by a conspicuous costa which marks the beginning of the curvature into the basal surface. This costa is broarl and angular and its upper slope is somewhat steeper than its lower one. Above this costa and separated from it by a distance of between one thirrl to one lialf of the width of the lateral surface is another slightly less prominent costa of sinilar character. The space between these two costae is broadly and evenly concave and bears a single fine thread-like costa. Alove the second prominent costa the surface is flat and smooth except for two delicate costae upon its lower part and a third along the upper edge just slightly below the angulation. Lines of growth are not conspicuous but can be made out here and there. They cross the lower edge of the lateral surface at nearly right angles and then curve strongly backward above, meeting the border of the slit band at a very acute angle.

The basal surface of the whorl is ornamenterl with numerous revolving costae which are separaterl from each other ly alout $1 \mathrm{~mm}$. over the greater part of this surface. On the outer portion, however, they are more widely spaced, the first one being separated from the costa marking the boundary of the basal surface by a distance only a little less than that between the two prominent costae of the lateral surface of the whorl. The second costa of the base is in turn separated from the first by a somewhat smaller interval and the spacing of the remainder is nearly uniform. These costae are very low ancl are separated from each other hy angular furrows which have long gentle outer slopes and short steep inner slopes. The costae of the base do not extend fown into the umbilicus. The holotype possesses about 15 costae upon its hasal surface. Growth lines have not heen olserverl upon this portion of the shell.

Remarks.-The species Irania pusilla may be listinguisherl from the the other similar species principally ly its much smaller size. It is not improbable that the shell rescribed above is a dwarferl form but nevertheless it is sufficiently distinct from $Y$. inclinata and $Y$. gurleyi to receive recogni- 
tion. Its chief points of difference are the relatively narrower slit band and the conspicuous outward sloping of the lateral surfaces of the whorls. In its ornamentation the species under discussion is intermediate between the other two. It is, however, more closely related to $Y$. inclinata than to $Y$. gurlcyi.

The holotype of this species is No. 7 in the collection of the Illinois State Geological Survey.

Occurrence. - This species occurs in a silicified conchition in a dark limestone near the base of the Pennsylvanian in the NIV. I/4 sec. 35, T. $21 \mathrm{~N}$, R. 9 W., Warren County, Indiana.

\section{YVANIA GURLEYI (Meek)}

Pl. III, figs. 1a-d, 7

1871 Plcurotomaria gurleyi. Meek, Acad. Nat. Sci. Phil., Pr. p. 117. Coal Measures: Danville, Illinois.

1873 Plcurotomaria Gurlcyi. Meek and Worthen, Geol. Survey of Illinois, vol. 5, Pl. 30, figs. 6a, b. Coal Measures.

1874 Plcurotomaria Gurlcyi. Meek, Am. Jour. Sci. (3) vol. 7, p. 584.

Dcscription.-Shell small, slightly turreted, spiral angle about $92^{\circ}$; whorls angular, base convex, umbilicus small; last whorl forms over half the height of the shell; surface marked by numerous revolving costae; slit band prominent, concave, slightly inclined to the upper sloping surface of the whorl and adjacent to the angle.

The dimensions of the holotype are: height of the entire shell $5.8 \mathrm{1mm}$.; lieight of the last whorl $3.2 \mathrm{~mm}$; and width at base $5.4 \mathrm{~mm}$. It is composed of five and three quarters whorls. The first turn is practically flat, the second is very low, and it is only in the later ones that the elevated spire is developed. The first two and one half whorls are uniformly convex. In the next the angularity appears and rapidly attains mature development. No markings are observed upon the surface of the first whorl. On the second whorl there appear a number of indistinct revolving striae. At the beginning of the third turn these resolve themselves into a series of seven, approximately equally prominent and equally spaced revolving costae. The space between the second and third of these, counting outward from the suture, is occupied liy the slit band. Early in the third turn this area becomes wider, and another revolving costa appears between the suture and the first costa previously visible. In the latter part of the third turn the costa bordering the slit band becomes relatively more conspicuous whereas the first one on the lateral surface below the band and the first one above it on the upper surface become very faint and shortly become obsolete. Also the lowest costa upon the lateral 
surface passes beneath the suture of the next whorl and disappears. Early in the fourth turn the next lower costa disappears in a sinilar mamer. Later in the course of this same tum two fine thread-like costae arise upon the broad smooth space adjacent to the band upon the upper surface. This number is subsequently increased to four.

The mature whorls are subrhomboidal in outline and are slightly wider than high. The outer surface is divided into three parts by two angulations the upper of which is sharply localized along the outer border of the slit band and forms an angle of about $120^{\circ}$, situated below the suture by about one fifth the height of the whorl. The lower angulation is little more than a regular inward curving of the shell from the flat lateral surface to the convex basal surface of the whorl. The lateral surface constitutes a little more than lalf the height of the whorl and is practically' vertical in position. The slope of the basal surface is gently and nearly uniformly convex into the umbilicus.

The whorls are practically non-embracing, as the spire is formed by each succeeding whorl being attached to little more than the basal surface of the preceding one. The suture is almost right angular and either follows or occurs slightly above the prominent costa which marks the beginning of the curvature into the basal surface of the preceding whorl.

The columellar lip is blunt and recurved upon itself but not greatly thickened. It extends over and partially hides a moderately sized umbilicus. No thickening or callosity is apparent upon the inner lip.

'The slit band is situated along the outer margin of the upper sloping portion of the whorl and is inclined slightly downward from its general direction. The band is equal in width to slightly more than one fifth of the complete width of the upper surface of the whorl and is bounded by two prominent costae having angular crests whose converging slopes give to the band a concave outline. No ornamentation is present upon its surface. Lines of growth, however, are faintly indicated by slightly concave transverse markings which neet the outer of the bounding costae at a position a little farther to the front than that at which they touch the inner.

The two costae bordering the slit band and a third costa adjacent to the suture are the most prominent markings upon the upper sloping surface of the whorl. The costa last mentioned is separated from the suture by a flat and nearly horizontal area a little wider than the width of the slit band. Ietween the upjer proninent costa and the slit band the surface is shallowly concave and carries as many as four fine threarl-like costae which are somewhat more promounced and closely spaced upon the inner upper portion. Lines of growth are well developed upon the upper surface of the whorl and are displayed by tine lirae and mevenuess of the shell surface. They are linguliform and attain their farthest forward position alout michay letween the 
inner edge of the slit band and the suture. They are here regularly convex and sweep backward to join the edge of the band at an acute angle. Toward the suture the growth lines extend in a sinuous curve, first convex but as the suture is approached the curve becomes slightly concave and they join the suture in a direction nearly normal to it.

The lateral slope of the whorl below the outer edge of the slit band is nearly as wide as the upper slope. It is arbitrarily bounded below by a prominent costa which marks the beginning of the curvature into the basal surface. This costa is narrow and angular and the slope upon the upper side is somewhat steeper than upon the lower. Above this costa and separated from it by a clistance somewhat less than one third of the width of the lateral surface is another similar or slightly more prominent costa. Above this to the slit band the surface is flat or smooth with the exception of growth lines which curve strongly backward and approach the border of the slit band at an acute angle. Between the two costae on the lower part of the lateral slope the growth lines are essentially normal to these markings.

The basal surface of the whorl is ormamented by numerous revolving costae separated from each other over the greater part by $.2 \mathrm{~mm}$. or less. On the outer portion, however, they are more wiclely spaced, the first two or three being separated from each other and the costa bounding the basal surface by spaces about equal to or slightly less than that which intervenes between the two costae of the lateral surface of the whorl. The costae of the base do not extend down into the umbilicus. The holotype possesses 12 costae upon the basal surface. The growth lines are very slightly concave in the central part of the basal surface, but as the umbilicus is approached they become slightly convex.

Rcmarks.-The species I'vania gurlcyi is very closely related to $Y$. inclinata from which it may be recognized by its slightly narrower slit band bounded by less prominent costae, the coarser nature of its other markings, the absence of fine costae upon the lateral surface of the whorl and of those adjacent to the suture on the upper surface.

The holotype of this species is No. 6351 in the collection of Walker Museum at the University of Chicago.

Occurrence.-This species was obtained in a beautifully pyritized condition from the black shales which overlie the Danville coal near Danville, Vermilion County, Tllinois.

YVANia SUPERCREnAta Weller, 11. Sp. Pl. I, figs. 2 a-3; Pl. III, fig. 8

Description.-Shell small, somewhat higher than wide, slightly turreted. spiral angle about $86^{\circ}$; whorls angular, base convex, umbilicus small; last 
whorl forms slightly less than half the height of the shell; surface marlied ly numerous revolving costae; slit band prominent, concave, located on the upper flattened surface of whorl and adjacent to the angle.

The dimensions of the holotype which is the most completely preserved specimen in our collection are: height of entire shell $4.8 \mathrm{~mm}$. ; height of last whorl $2.2 \mathrm{~mm}$; ; and width at base $4.6 \mathrm{~mm}$. It is composed of about six and one half whorls. The first three turns of the spire are uniformly convex and smooth. Early in the course of the fourth turn the revolving costae appear, first upon the lateral slope adjacent to the lower suture and then progressively above until four are present. The two central costae represent those which bound the slit band, the lower one is the upper large costa of the lateral surface of the whorl. The uppermost costa continues prominently on all the later whorls adjacent to the suture. Additional costae originate by implantation at various stages in the development of the shell. The regular convex outline of the whorls persists into the fifth turn during the course of which, howerer, the angulation of the mature portion of the shell develops and the slit band, which up to this time had been inclined, becomes more nearly horizontal and takes its position upon the outer edge of the upper flattened portion of the whorl.

The mattre whorls are subrhomboidal in outline and are wider than high. The outer surface is divided into three parts ly two angulations: the upper is sharply localized forming an abrupt angle of about $130^{\circ}$, situated below the suture by between a quarter and a third the height of the whorl; the second, which is located below the first ly alont half the height of the whorl, is less localized and more in the nature of a sharp inward curving of the shell. The upper slope is flat and inclined slightly downward from the suture. The lateral slope is vertical in position and flat or slightly concave in outline. The basal surface is gently and rather evenly convex. The convexity may or may not locally increase notally as the basal surface slopes into the umbilicus.

"The whorls are practically non-embracing as the spire is formed by each whorl builling downward and outward from the base of the precerling one to which it is attached. The suture is sharp, angular, and slightly excavated due to the conspicunus parallel costa upon the upper surface of the later whorl. The suture closely follows the position of the prominent costa which marks the lower angulation of the precerling whorl.

The columellar lip is blunt and recurved upon itself but not much thicker than the rest of the shell. It extends over and partially hides the umbilicus which is small and shaperl like a comma, leing romded at one end and clrawn out to a curved point at the other. There is no thickening or callosity of the inner lip. Several specimens inclicate that there was partial but not complete resorbtion of the basal ornamentation for a short distance within the aperture. 
The slit band is situated along the outer margin of the upper flattened portion of the whorl and is equal to about one fourth of the width of this surface. It is bounded by two prominent costae having narrowly rounded crests and slopes which are concave toward the slit band and give this portion of the shell a broadly concave appearance. On the mature portion of the shell the band may be ornamented by one or more fine revolving costae. No transverse markings or lines of growth have been observed upon the slit band.

A prominent costa, similar to the one which occurs upon the inner edge of the slit band, lies upon the upper surface of the whorl next to the suture. Between these two costae on the last whorl of the holotype occur two others which are locally almost if not quite as prominent as the one adjacent to the suture. No transverse. ornamentation exists upon the upper slope of the whorl and no lines of growth have been observed on any of the specimens examined.

The lateral slope of the whorl below the outer edge of the slit band is nearly as wide as the upper slope. It is bounded below by a prominent angular or narrowly rounded costa and bears upon its surface another conspicuous costa about one third of the distance above the lower one. This latter costa is steeper upon its upper slope than its lower and the space between it and the lower one is asymmetrically concave with the deepest portion about three fourths of the way to the lower costa. The upper two thirds of the lateral surface of the whorl is practically flat or only slightly concave and extends smoothly from the crest of the outer bounding costa of the slit band, which produces the sharp angularity of the shell, to the base of the costa below. Lines of growth upon the lower third of the lateral surface are nearly vertical between the costne, but alove they bend sharply backward to the edge of the slit band.

The basal surface of the whorl is ornamented by numerous low, steplike costae having steep outer slopes and long gentle inner slopes. The outermost of these is separated from the costa which marks the lower angle of the whorl by a distance about equal to that which separates the two costae of the lateral slope. Inward upon the basal slope the costae become progressively more closely spaced until those upon the edge of the umbilicus are separated by less than $.2 \mathrm{~mm}$. These costae apparently do not continue all the way down into the umbilicus or else they become too faint to be discernable. The holotype possesses 11 costae upon its lasal surface but this number may be variable and dependent to some extent upon the size of the shell. New ones if added make their appearance out of the umbilical depression and never by implantation. Growth lines upon the basal surface show that the aperture was broadly concave in this part. 
Remarks. - The species louniu suporronata is very closely allied to $I$. hamghti from which it may be distingruished ly its relatively natrower band, the more numerous revolving costac above the band, the greater prominence of the costa adjacent to the suture, the ornamentation which may occur upon the band, the less prominent custa upon the outer border of the band, the lesser concavity of the smonth area just below it, the more comvex basal surface, the presence of at well formed mulpilicus, the more equal spacing of the costae of the basal surface, and the uniform enlargement of the whorl resulting in a more regular spire.

Iatania supererenala may be distinguished from $\mathrm{l}$. inclinata with which it is associated by its slit hand which lies in the plane of the upper surface of the whorl, the flatness of the upper surface, the higher spire, the fewer and coarser revolving costae, and the less uniform spacing of the costae upon the basal surface.

The holotype of this species is No, 1 in the collection of the Illinois State Geologrical Survey.

Occurrcucc.-This species occurs in a limestone bed which closely unlerlies the Colchester (No. 2) coal over large areas in western Illinois. The holotype and a series of other specimens were collected from an outeriop in the northeast bank of Wilson Creek near the southwest corner sec. 26 , T. 3 N., R. 2 E., Fulton County, Illinois.

\section{YviNiA KNigiti Weller, n. sp.}

PI. I, figs. 5-8; Pl. III, fig. 9

Description.-Shell small, higher than widle, turreted, spiral angle about $75^{\circ}$; whorls angular, base slightly convex, umblilicus closed; last whorl forms less than half the height of the shell: surface marked by numerous revolving costae; slit band prominent, concave, located on upper flattened surface of whorl and adjacent to the angle.

The dimensions of the holotype are: length of entire shell $7.6 \mathrm{~mm}$.: leight of last whorl $3.3 \mathrm{~mm}$. : anrl width at hase $6.4 \mathrm{~mm}$. This specimen is composerl of seren whorls, the first four of which are miformly convex. The early ones are smonth lut at the beginning of the fourth turn four revolving costae are conspicursusly developerl. These are of about exual size, are uniformly spaced, and the second and third enclose the area of the slit hand. During the course of the fourth turn the characteristic mature angulation develops, due principally to the more prominent development of the costac which bound the band. The interspace below the band increases somewhat in width lut the upper slope of the whorl remains dividerl into three areats of almost equal wirlth until in the course of the sixth turn the interspace above the band lecomes relatively wirler and there appears upon its surface 
a centrally located, fine thread-like costa which gradually becomes stronger. The later whorls of some of the larger specimens are enlarged at a rate which is somewhat less rapid than that of the younger whorls and the result is a spire having a slightly convex profile.

The mature whorls are subrhomboidal in outline and are somewhat wider than high. The outer surface is divided into three parts by two angulations the upper of which is sharply localized and forms an abrupt angle of about $125^{\circ}$, situated below the suture by about one third the height of the whorl. The second, which is located below the first by a little less than one half the height of the whorl, is less localized and more in the nature of a sharp inward curving of the shell. The upper slope is flat and inclined slightly downward from the suture. The lateral slope is vertical in position and slightly concave in outline. The basal surface is gently convex, curving into the columella.

The whorls are practically non-embracing as the spire is formed by each whorl building downward and outward from the base of the preceding one to which it is attached. The suture is distinct and occurs at or near the position of the prominent costa which marks the lower angulation of the preceding whorl.

The columellar lip is somewhat thickened and recurved and completely or nearly closes the umbilicus. There is no thickening or callosity on the inner lip.

The slit band is situated along the outer margin of the upper flattened portion of the whorl and is equal to one third of the entire width of this surface. It is bounded by two prominent costae having narrowly rounded crests whose converging slopes give the band a broadly concave profile. The band is unornamented by spiral markings and lines of growth are rarely preserved upon it. Where they do remain they are seen to be unevenly crescentic with the axis of the sinus located above the middle of the band so that the growth lines meet the outer costa at a position a little in advance of their junction with the inner one.

The flat upper surface of the whorl bears two costae between the suture and the costa which lies upon the inner side of the slit band. These may be equally prominent or the lower one may be less conspicuously developed, but never are they quite as pronounced as those which bound the slit band. The spacing of the upper costae may be equal or not; where it is not the lower costa is usually much the smaller. Lines of growth are rarely to be observed but where present they show that this portion of the aperture was convex and linguliform and curved strongly backward toward both the suture and the slit band.

The lateral slope of the whorl below the outer edge of the slit band is nearly as wide as the entire upper slope. It is bounded helow by the begin- 
ning of the curvature into the hasal surface which occurs at the position of a prominent revolving costa. L pon its surfice is another costa, the distance between the two varying from one third to nearly one half of the width of the lateral slope. Both costae are steeper above than below and the space lotween then is asymmetrically concave with the deepest portion three qualters of the distance to the lower costa. The upper portion of the lateral slope is shallowly concave, due to the prominence of the costa along the outer edge of the slit band. Growth lines where visible show a strong backward sweep toward the slit band above and a convex curve below, crossing onto the basal surface with a slight backward inclination.

The loasal slope is marked ly numerous low step-like spiral costae having steep outer slopes and long inner slopes. The outer of these costate are separated by chistances about equal to that which intervenes between the two costae of the lateral surface. There may be two, three, or four such broad interspaces and then they become much narrower and continue so to the columellar region. The number of the costae may vary from alout ten to fifteen, depending largely upon the spacing of the outer ones. The growth lines are curved, broadly and shallowly concave on the outer half of the basal surface, and continuing nearly straight toward the columella but becoming slightly convex just before they reach it.

Remarks.-The species Irania knighti is closely related to $Y$. supercrenata from which it may be distinguished by the greater relative width of the band, the fewer revolving costae above it, the lesser prominence of the costa adjacent to the suture, the unornamented character of the band, the more prominent costa upon the outer border of the land, the concavity of the smooth area just below the band, the flatter lasal surface, the general absence of an umbilicus, the more mequal spacing of the costae of the lasal surface, and the inerpuality in the enlarging of the whorls resulting in a spire having a slightly convex profile.

The holotype of this sprecies is No. 3 in the collection of the Illinois State Geological Survey.

Occurrence.-This species occurs abundantly in the Piasa limestone of St. Louis County, Missururi. The holotype and a series of other specimens were obtained from weathererl limestone that was temporarily exposed ly. gracling in the Davis Sublivision, one mile south of Clayton.

\section{Yrixid s.minexsis Weller, 11. sp.}

Pl. I, figs. 9-10c

Description.-Shell small, higher than widle, turreterl, spiral angle alout $63^{\circ}$ : whorls angular, lase slightly comvex, nmbilicus small or entirely closed: last whorl forms about two fifths the height of the shell: surface marked 
by revolving costae; slit band prominent, concave, located on the upper flattened surface of the whorl and adjacent to the angle.

The dimensions of the holotype are: height of the entire shell $7.4 \mathrm{~mm}$. ; height of last whorl $2.9 \mathrm{~mm}$.; and width at base $5.8 \mathrm{~mm}$. It is composed of about seven whorls. Nune of the specimens in our collections are sufficiently well preserved to determine the progressive development of the shell from the embryonic state to maturity.

The nature whorls are subrhomboidal in outline and are wider than high. The outer surface is divided into three nearly equal parts by two distinct angulations the upper of which is the more sharply localized and forms an angle of about $130^{\circ}$, situated below the suture by about one third the height of the whorl. The lower one, which is located below the first by about one third the height of the whorl, is more in the nature of a sharp inward curvature of the shell. The upper slope is flat and inclined slightly downward from the suture. The lateral slope is nearly vertical in position and broadly concave in outline. The basal surface is somewhat depressed, only gently convex, and curves slightly into the umbilical region.

The whorls are practically non-embracing, each subsequent one being attached merely to the basal surface of its predecessor. The suture is sharp, angular, and impressed, and follows just below the prominent costa which marks the lower limit of the lateral surface of the preceding whorls.

The columellar lip is somewhat thickened and recurved upon itself. It either extends over and completely closes the umbilicus or almost does so; which it does could not be determined satisfactorily from the specimens examined. There is no thickening or callosity on the inner lip.

The slit band is situated along the outer nargin of the upper flattened portion of the whorl and is equal in wiclth to a little less than one third the total width of this surface. It is lounded by two prominent costae whose converging slopes give to the band a broadly concave outline. It bears no ornamentation and growth lines are not visible.

Two costae about as prominent as those which bound the slit band occur upon the upper portion of the upper surface of the whorl. The inner one is separated from the suture by a smooth level area a little over half as wide as the band. It is this area in combination with the prominent costa above which gives the suture its sharply impressed condition. The second of the two costae occurs below the first and is separated by a space equal in willth to the area between the upper costa and the suture. The space between the costa upon the inner edge of the hand and the lower of the two costae described above is as wide or slightly wider than the band and resembles it in general appearance except that it is somewhat more concave. No growth lines have been observed upon this portion of the shell. 
The lateral slope of the whorl helow the outer elge of the slit hand is sonewhat narrower than the upper slope. It is strooth and broadly concave, and is hounded below he the most prominent costa on the whole shell. Growth lines have not heen olserved upon this part of the whorl.

The hasal slope of the whorl hears a proninent costa within and helow the larger one which marks the boundary between this part of the shell and the lateral surface. They are separated by a space somewhat less than the width of the slit band. Lpon the inside of this costa is a shallow concatve furrow similar to those which separate the costae on the basal surface of other species in this genus, hut in this case no costa rises upon the insicle of it and the hasal surface is sunooth for the remainder of the distance to the columella. It is entirely possible that the lasal surface was originally ornamented ly adrlitional spiral costae that have been destroyed and do not nplear upon the imperfectly preserved specimens examined. This is indicated hy one specimen which preserves indistinct traces of a few fine costae adjacent to the columella. On the other hand this species is closely similar to $Y$. adamsi, upon the central part of the base of whose whorls $I$ have never observerl costae, a fact suggesting that most of the basal surface of the species under discussion was probably smooth. No lines of growth have heen observed upon the basal slope of the whorl.

Remarks.-The specimens upon which the species Yvanin salincnsis is erecterl are poorly preserved as compared to other forms described in this paper. Although much of the surface rletail has been destroyerl, enough remains to characterize this species in a reliable manner. It is possible that the future cliscovery of nore perfect specimens will reveal some more delicate surface markings than those described above.

Y'ania sulincusis is closely related to $Y$. adansi from which it may be distinguished ly the more acute spiral angle, the more convex base, the less concave lateral slope and the single costa which marks its lower linit, and the sharply impressed suture.

The holotype of this species is No. 5 in the collection of the Illinois State Geological Survey.

Occurrence. - This species (xecurs in the limestone cap) rock of the Herrin (No. (1) coal at the rairoarl cur in the SII. 1/4 NII. I/4 sec. 31, T. 9 S., R. 6 E., near Ledford. Saline Cinn1ty. Illinois. 
YVANIA ADAMSI (Worthen)

Pl. II, figs. 1-3b; Pl. III, fig. 4

1884 Plcurotomaria adamsi. Worthen, Illinois State Mus. Nat. Hist., Bull. 2, p. 5.

Coal Measures: Peoria County, Illinois.

1890 Plcurotomaria adansi. Worthen, Geol. Survey of Illinois, vol. 8, 1. 137, Pl. 23, figs. 5-5a.

Coal Measures: Peoria County, Illinois.

Description.-Shell small, a little higher than wide. trochiform, spiral angle about $65^{\circ}$; whorls angular, base nearly flat, tumbilicus small; last whorl forms somewhat over one third the height of the shell; surface marked by revolving costae; slit band prominent, concave. located on upper sloping surface of the whorl and adjacent to the angle.

The dimensions of an average specimen are: height of the entire shell $7.1 \mathrm{~mm}$. ; height of the last whor $2.8 \mathrm{~mm}$. ; and width at base $6.2 \mathrm{~mm}$. About seven whorls are present in mature individuals. The first two and one half whorls are uniformly convex. Two revolving costae become apparent at about this stage in the development and are located a little above the periphery of these rounded whorls. These costae inclose the area of the slit band. They gradually become more prominent and during the course of the fourth turn the shell takes on its mature form and ornamentation.

The mature whorls are subrhomboidal in outline and are wider than high. The outer surface is divided into three parts by two distinct angulations, the upper of which is sharply localized along the costa which marks the outer edge of the slit band. The angle of this edge is slightly acute but che to the slight concavity of the band and the greater concavity of the lateral surface of the whorl these two sicles of the whorl form an angle of about $130^{\circ}$. This angle is situated below the suture by slightly less than one third the height of the whorl; the lower angle is located below the first by a little less than half of the height of the whorl. The upper surface is flat and inclined downward and outward from the suture. The lateral surface is nearly vertical in position and rather strongly concave in outline. The basal surface is much depressed, only slightly convex, and curves into the umbilicus with a sontewhat greater inclination.

The whorls are non-embracing, each subsequent one being attached merely to the basal surface of its predecessor. The suture is rather inconspicuous and may be either angular or rounded, dependling upon its exact position. It usually follows the lower of the two costae which occur upon the lower horder of the lateral surface but it may vary from slightly above to slightly below this position. 
The columellar lip is sonewhat thickened and recurved upon itself. It extends over and partially hicles the shallow umbilicus. There is no thick(ninter or callosity developed mpon! the inner lip.

The slit hand is situated along the outer margin of the upper flattened portion of the whorl and accupies slightly less than one third the wiclth of this surface. It is bouncled by two pronninent costae whose converging slopes neet about one fourth of the way bekw the upper costa and thus produce the asymmetrically concave band. No markings of any kind have been obstreel upon the banrl.

A prominent costa occurs upon the upper flattened surface of the whorl adjacent to the suture but separated from it by a space equal to about half the widtl of the slit band. This costa is about as proninent as the one bounding the inner sicle of the band. Upon the final whorls a second costa somewhat finer than the first occurs below the first ancl is separated from it by a space equal in width to that between the first costa and the suture. The space between the costa upon the inner edge of the band and the lower of the two costae described above is about as wide as or slightly wider than the slit band and resembles the band in general appearance except that it somewhat flatter. No growth lines have been observed upon this portion of the shell.

The lateral slope of the whorl below the outer erlge of the slit band is somewhat narrower than the upper slope. It is bounded below by a prominent keel which bears upon its crest two costae of about equal developnnent although the lower projects beyond the upper. Together the costae are somewhat narrower than the slit band but the space between them does not resemble the band as it is nuch narrower and relatively more concave. A smooth concave surface separates these costae from the upper angle of the whorl and makes up about three fourths of the lateral surface. The surface is usually somewhat asymmetrically concave. the steepest part being in its lower portion. No lines of growth have been observed upon this portion of the shell.

The basal surface of the whorl bears two or three costae on its outer portion. The outermost of these is the most prominent, but is somewhat less conspicuous than the costae on the lower part of the lateral slope. The second costa of the base is slightly less developerl than the first, and the third where present is very fine and threari-like. The first costa of the base is separated from the edge by a space slightly wider than that which separates the two crstae of the lateral surface. The space between the first and second costae nf the base may he about equal to or slightly greater than the space between the first and the edge of the basal surface. The space between the second and third costae where the latter is developed is considerably greater. The central part of the basal surface is without ornamentation but fine costac 
appear upon the slope from the basal surface into the umbilicus, three or four of these having been observed upon one specinen. Lines of growth upon the base are broadly and gently concave and have a slight backward sweep, becoming slightly convex in the umbilical area.

Remarks.-The species Yiania adamsi is most closely related to $Y$. salincnsis, from which it may be clistinguished by the less acute spire, the flatter base, the more concave lateral slope and the double costa which marks its lower linit, the less prominent suture, and the general trochiform shape.

The holotype of this species is cataloguerl as No. 2536 in the paleontological collection of the Illinois State Museum. A substitution of specimens has however apparently taken place for the specimen bearing this number is not $Y$. adamsi and the type of this species has not been located.

Occurronce.-This species is typically developer in the Lonstale limestone. It is present in many collections from this horizon but the preservation is very rarely such that the details of the external features may be noted. The specinens illustrated on T'late II are from the NW. I/4 sec. 34, T. $8 \mathrm{~N}$. R. 6 E., Peoria County, Illinois. The exact locality from which the type of this species was obtained is unknown.

\section{Yvania subconstricta (Meek and Worthen)}

Pl. II, figs. $4 a-5 c$; P1. III, fig. 10

1860 Plcurotonaria subconstricta. Meek and Worthen, Acad. Nat. Sci. Phil., Pr. p. 458.

Coal Measures: Hodge's Creek, Macoupin County, Illinois.

1866 Plenrotomaric subconstricta. Meek and Worthen, Geol. Survey of Illineis, vol. 2, p. 351, Pl. 28, figs. 6a-c.

Lower Coal Measures: Hodge's Creek, Macoupin County, Illinois.

Description.- - Shell small to medium sized, higher than wide, subtrochiform to slightly turreterl. spiral angle alonut $60^{\circ}$ to $70^{\circ}$; whorls angrular, hase convex, not 11mbilicated; last whorl forms a little more than half the height of the shell: surface marked by numerous revolving costae which are nodose adjacent to the suture, and by transverse lines of growth ; slit band proninent. flat, lncated on the upper sloping surface of whorl and adjacent to the angle.

The dimensions of an average specimen are: height of entire shell $7.4 \mathrm{mmm}$. ; height of last whorl $4.2 \mathrm{~mm}$.; and wilth at base $6.1 \mathrm{~mm}$. This specinen is composed of about seven whorls. Another individual, the largest one that has been obtained, has the following measurements: height of entire shell $12.6 \mathrm{~mm}$. ; height of last whorl $7.4 \mathrm{mrn}$.; and width at base $8.9 \mathrm{~mm}$. It is made up of about eight whorls. The first three turns of the spire are uniformly convex. The first two are coiled in a practically flat spiral but thereafter the spire is uniformly developerl. Upron the third whorl 
five equally prominent and uniformly spaced spiral costac are apparent. The sit hand recupies the space above the central costa. Early in the fourth turn the slit hand hecomes proportionately wider and more prominent and the angulation along its outer border hegins to become apparent. Also the hwest of the costac mentioned above lisappears beneath the suture. On the latter part of the fourth turn a fune threal-hile costa appears by implantation in the interspace above the slit band and another fine costat is developed below the band. In the conrse of the lifth turn the whorl becomes essentially mature in all its characters. The costa adjacent to the suture becomes quite prominent and markis a listinct angle between the slophing npper surface of the whorl and the narrow level shelf along the suture. This costa, and sometimes the next lower one, becomes nodose. Adkitional costac are introduced within the area between the nodose costa and the slit band, as they also are upon the lateral slope of the whorl helow the slit hand. The last whorl of the large specinen mentioned above shows gerontic development, chiefly evinced hy the costae of the upper slope of the whorl hecoming obsolete and the srowth lines becoming much more rugged and conspicuous. In addition to this change in ornamentation the slit band becomes shightly concave.

The mature whorls are subrhomboidal in outline and are wider than they are high. The outer surface is divided into thee parts by two angulations in adclition to which a thircl angulation occurs along the upper border of the whorl adjacent to the suture. The uprere of the two main angulations is situated along the outer edge of the slit hand and forms an angle of about $135^{\circ}$. This angulation occurs below the suture ly somewhat more than one third the height of the whorl. The second angulation is located lelow the first hy slightly less than one thirel the height of the whorl. it is not as sharp as the upper one lut marks the alorupt inward curve of the hasal surface. The upper surface is rather shaply concave just above the slit land. From this depression the surface slopes ontward to the marerin of the slit hand and upwarl to the angulation which occurs aljacent to the suture. 'This latter angulation is one of ahout $125^{\circ}$ and is separated from the suture ly a narrow horizontal area. The lateral surface of the whort is slightly concave. In most cases it slopes inward a little due to the greatest dianeter of the sheli heing deveioped along the edge of the slit hand. The lasal surface is regularly convex and shepes evenly into the columellar area.

The whorls are non-embracing. each one being attached to the hase of its predecesoser. The suture is sharp, angular, and may be slightly excavated. It closcly follows the costa which marks the lower main angulation of the precerling whorl.

The columellar lip is strongly recurverl upon itself and comsilerably thickenerl. It extends orer and in most specimens completely choses the 
umbilicus. There is no thickening or callosity developed upon the inner lip. Some specimens seem to indicate that resorbtion of the spiral costae took place within the aperture.

The slit band is situated along the outer margin of the upper sloping portion of the whorl and occupies from slightly more to slightly less than one third the width of the surface between the angulation along its outer border and the angulation adjacent to the suture. It is essentially flat and is bounded by two low narrow angular costae. Its surface is covered by numerous fine crescentic, transverse costae which show the form of the sinus. They are low and rounded, closely though irregularly spaced, and are separated by interspaces, the wider of which are flat. These crescentic costae are somewhat asymmetrically curved, the greatest concavity occurring above the middle of the band so that they meet the outer edge in a position somewhat more advanced than their junction with the inner boundary. No revolving ornamentation is present upon the slit band.

The most conspicuous costa upon the upper surface of the whorl occurs upon the angle adjacent to the suture. Below this angle and above the costa which marks the inner side of the slit band occur two to four additional costae. Each of the lower ones is in turn smaller than the ones above and the lowest may be finer than those that bound the band, from which they differ in being rounded. In a few cases the first costa below the one which occupies the angle is equal to it in size. The interspaces which separate these costae in general are progressively somewhat narrower between the lower finer costae. The narrow, flat, horizontal area adjacent to the suture is about equal to or slightly narrower than the slit band. The sloping surface between the edge of the band and the angle bounding the horizontal surface along the suture is about one and one half times or more often twice as wide as the band. Lines of growth are well developed upon the upper surface of the whorl. On the narrow flat area adjacent to the suture they bend backward and meet the suture at an angle slightly acute, or they become concave and develop a small sinus. The lines of growth on this portion of the shell may be somewhat grouped and form rounded transverse ridges. Upon the sloping portion of the upper surface the growth lines extend slightly forward from the angle which parallels the suture. The most forward position is reached in the upper part of this area. They then make a gently convex curve and sweep strongly back, meeting the edge of the slit band at an acute angle The nodose character of the costa occurring on the angle adjacent to the suture, and on some specimens of the next lower one, is associated with the lines of growth, but where growth lines cross the lower costae only minor irregularities occur.

The lateral surface of the whorl is about equal to or slightly wider than twice the width of the slit band. It is bounded below by a prominent rounded 
costa and bears upon its surface three or less commonly four more. 'These costae are not quite as prominently developed ats the one along the lower boundary of the lateral slope and are somewhat more closely spaced on the upper portion of this surface. Where the fourth costa is present it is very fine and is located just helow the angle. These costae are rounded and the interspaces are gently concave to flat. Lines of growth are conspicuous on this portion of the shell. They cross the lowest hounling costa at about right angles but just above it they hend sharply forward and traverse the first interspace in a cliagonal (lirection: in the second interspace they are approximately vertical hut swing strongly hackward on the remainder of the lateral slope and meet the elgge of the slit band at an acute angle. The growth lines are conspicuous only in the interspaces and are not visible crossing the revolving costae except for slight irregularities which they produce.

The basal surface carries about eleven rounded spiral costae separated by concave interspaces. The costae are rather uniformly spaced except in the region of the columella where the spaces are somewhat narrower. A few specimens show the outer costae as well as the inner spacel somewhat more closely than those which occuly the central part of the basal surface of the whorl. Lines of growth are fairly distinct. From the outer angle they sweep very gently bickward in a broad shallow concave curve to the midclle part of the basal surface: on the imner portion a slight convexity is developed in the vicinity of the colmella.

Remarks.-The species Irania subconstricta is closely related to $Y$. giffordi from which it may be distinguished by its less acute spire, the wider slit band, and the horizontal area arljacent to the suture.

The holotype of this species is preserved in the paleontological collection at the Lniversity of Illimis.

Occurrence.-This species was originally described from an outcrop of the limestone which underies the lielleville (No.6) coal on Horlges Creek in the SIV. $1 / 4$ sec. 30, T. 10 N., R. 9 IV. Macoupin County, Illinois. It has subsequently been collected from the same horizon in Greene Connty, the limestone cap rock of the Herrin (No. 6) coal in Saline and Gallatin Counties. Illinois, the Piasa limestone in St. Louis County, Missouri, and from the Lonsdale limestone in Peoria County, Illinois. This stratigraphic range is greater than has been olserverl for amy of the other species of Yrania in our Coal Measures strata. Most of the other species, so far as is known at present. are confined to a single horizon. lut future investigation will probably reveal that each of these also occurs in other neighboring horizons.

Since this paper was prepared a representative of this species has been recognized in a collection marle from the Drum limestone at Kansas City. Missouri, during the stummer of 1928. 


\author{
IVANIA GIFFORDI ( 1 orthen) \\ Pl. II, figs. 6-8b; Pl. III, figs. 5, 11
}

1884 Pleurotomaria giffordi. Worthen, Illinois State Mus. Nat. Hist., Bull. 2 p. 5.

Cual Measures: Yeoria, Illinois.

1890 Pleurotonaria giffordi. Worthen, Geol. Survey of Illinois, vol. 8, p. 135. Pl. 23, figs. 8-8a.

Coal Measures: Peoria County, Illinois.

Uescription. - Shell small to medium sized, one and one half times as high as widle, spiral angle about $45^{\circ}$ to $50^{\circ}$; whorls angulated, base convex, not umbilicated; last whorl forms slightly less than half the height of the shell; surface marked by numerous revolving costac which are nodose adjacent to the suture, and by iransverse lines of growth; slit band prominent, Hat, located on upper sloping surface of whorl and adjacent to the angle.

The dimensions of an average individual are: height of entire shell $9.0 \mathrm{~mm}$. ; height of last whorl $4.0 \mathrm{~mm}$. ; width at base $6.0 \mathrm{~mm}$. It is composed of about seven whorls whose development is probably very similar to that of $Y$. subconstricta. The specimens examined, however, are not sufficiently well preserved to show these details.

The mature whorls are subrhomboidal in outline and of about equal height and width. The outer surface is divided into three parts by two angulations in arldition to which a third minor angulation occurs adjacent to the suture along the upper border of the whorl. The upper of the two main angulations is situated along the outer edge of the slit band and forms an angle of alout $140^{\circ}$, occurring luclow the suture by slightly more than one third the height of the whorl. The second angulation is located below the first by somewhat less than one third the height of the whorl. It is not as sharp as the upper one but marks the beginning of the sharp inward curve of the basal surface. The upper slope is constricted and concave just above the slit band. From this constriction the surface slopes outward to the margin of the slit band and upward to the angulation which occurs adjacent to the suture. This last angulation is one of about $115^{\circ}$ and is separated from the suture by a narrow horizontal area. The lateral surface of the whorl is concave and is approximately vertical in position. The basal surface is regularly convex and slopes evenly into the columellar area.

The whorls are non-embracing, each one being attached to the base of its predecessor. The suture is sharp, narrowly concave to angular, and may be slightly excavated. In the upper whorls of the spire it rather closely follows the position of the costa that marlis the lower limit of the lateral surface of the preceding whorl, but in the later turns it commonly follows a somewhat 
lower position so that a narrow strij) of the basal surface of the preceling whorl reminins visible.

The colmuellar lip is strongly recmed upon itself and considerably thickened. It extends over and in most cases completely closes the umbilicus. There is no thickening or callosity developed upon the imer lip.

The slit band is located along the outer margin of the mper sloping frortion of the whorl and eceupies a zone sonewhat less than a half but ustually more than at third of the width of the surface between the angulation along its outer border and the angulation adjacent to the suture. The slit hand is essentially flat and is bounded by two low narrow angular costac. Its surface is covered by numerous tine crescentic transverse costae which are closely though irregularly spaced. They are asymetrically curved, the greatent concavity occurring alove the mieldle of the band so that they meet the onter edge in a position someuhat more adranced than that of their junction with the imer boundary. No revolving ornamentation is present upon the slit band.

The most conspicuous costa upon the uper surface of the whorl occurs upon the angle aljacent to the suture. Below this angle and above the costa which marks the inner ride of the slit hand uccur on most specimens two additional costae which become olsolete in the gerontic stage in the growth of the shell. The nartow flat horizontal area aljacent to the suture is alout two thirds as wide as the slit hand. Lines of growth are well dereloned ipon the upper surface of the whorl. On the narrow flat area adjacent to the suture they extend sharply backward, curve into a small sinus and join the suture at nearly right angles. The lines of growth on this portion of the shell may be somewhat gromped and fom low rombed transierse ridges. Lpont the stoning portion of the mpper surface the enowth lines are linguliform. reaching their mont forward pesition slightly alowe the mirlle, from which they sweep backward to the upper angulation and more strongly to the border of the blit hand which they meet at a very ante angle. The norlese character of the costa occurring on the angle alljacent to the suture is associaterl with the erowth markings. !nt where growth lines cross the lower costae mly minor irregularities secur.

The lateral sope of the whorl is fromi two to two and one half times as wide as the slit hand. It is lummled below ly a broal rombled costa and hears upon its surface two or three smaller costac that are commonly finer and mone closely spacerl towarl the upper burder. These contate are rounderl and the interspaces are encutly concale to flat. I.ines of growth are contspicuous on this portion of the shell. They cross the lowent brumeling costa at alout right angles hut just alone it they bend sharply forwand and traterse the first interspace in a diagonal direction: in the second interspace they 
are approximately vertical or slightly convex forward but they swing strongly backward on the remainder of the lateral slope and meet the edge of the slit band at an acute angle. The growth lines are conspicuous only in the interspaces and are not visible crossing the revolving costae except for slight irregularities which they produce.

The basal surface carries about ten to twelve rounded spiral costae separated by concave interspaces. In rare cases this number may be as great at seventeen or eightecni. The interspaces are commonly slightly wider in the central portion of the basal surface of the whorl. The outermost costa generally occurs very close to the one which marks the angle between the lateral and basal surfaces. On those specimens where an unusually large number of costae are present upon the basal surface they are much more closely spaced in the colamellar region than over the remainder of the base. Lines of growth are fairly distinct and appear as fine transverse costae in the interspaces. From the outer angle they sweep very gently backward in a broad shallow concave curve to the middle part of the basal surface, and become slightly convex in the vicinity of the columella.

Rcmarks.-The species Yvamia giffordi is very closely related to $Y$. subconstricta which occurs principally at somewhat lower horizons. $Y$. giffordi may be distinguished principally by its more acute spire but also by its relatively narrower slit band and the horizontal area adjacent to the suture. At most localities the specimens are badly exfoliated and the surface features cannot be observed.

The holotype of this species is No. 2535 in the paleontological collection of the Illinois State Museum.

Occurrence.-This species was originally described from Peoria County, Illinois, without notation as to either locality or horizon. This gastroporl is one of the most characteristic members of the Lonsdale limestone fama and is present in most of the collections from this horizon in Peoria County and vicinity. Two specimens in the Gurley Collection preserved in Walker Museum at the University of Chicago are labeled as having been obtained from above coal No. 7 in Peoria County. The accuracy of this reference seems doubtful as the specimens are preserved much like some of those obtained from the Lonsdale limestone and this latter horizon is the only one from which I have oltained this species. 
PLATES AND EXPLANATIONS 


\section{EXPLANATION OF PLATE I}

All figures are enlarged four diameters

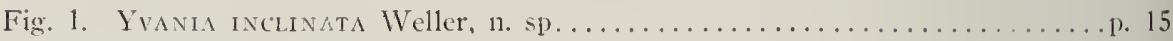
The holotype.

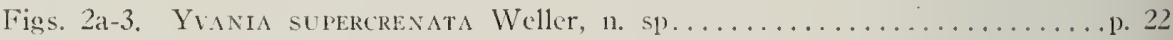
2a, b. The holotype.

3. A paratype.

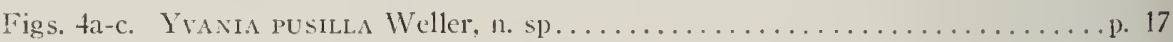

The holotype.

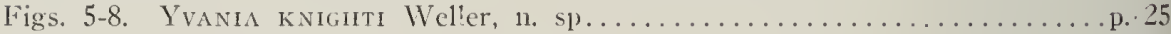
5. The holotyje.

6-8. Paratypes. The basal view slows a specimen whose outer costae are more widely spaced than usual.

Figs. 9-10c. Yvania salinensis Weller, n. sp...................... 27 9. A paratype.

10a-c. The holotype. 


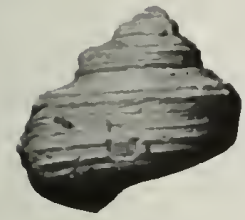

I

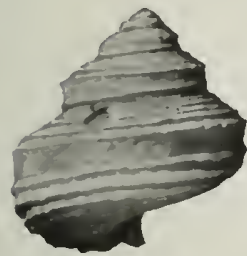

$2 A$

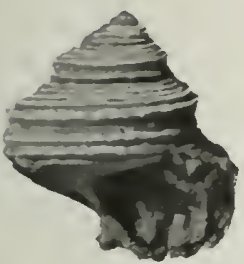

$2 B$

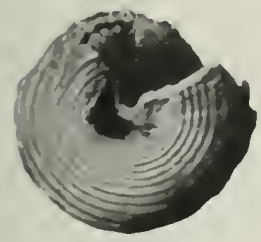

3

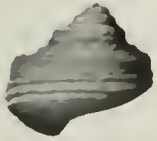

$4 A$

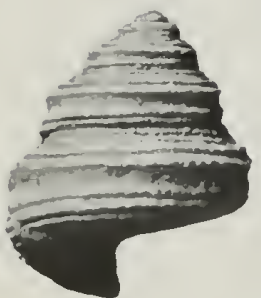

5

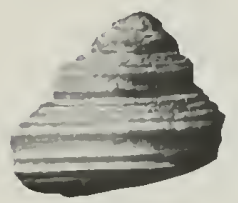

6

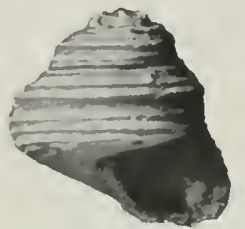

7

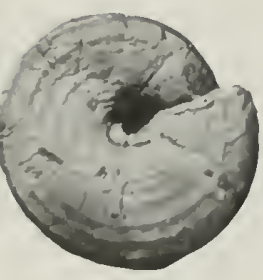

8

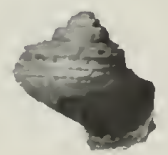

$4 B$

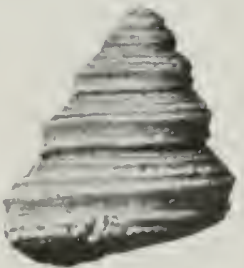

9

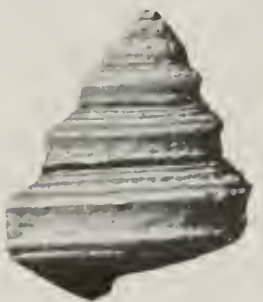

1OA

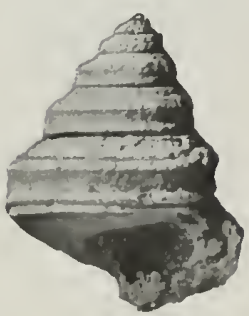

1OB

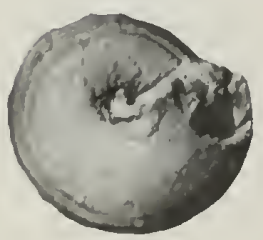

100

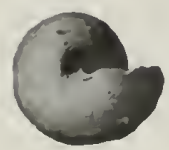

$4 c$ 


\section{EXPLANATION OF PLATE II}

All figures arc enlarged four diameters except $4 \mathrm{~b}$ and 9 which are enlarged eight diameters.

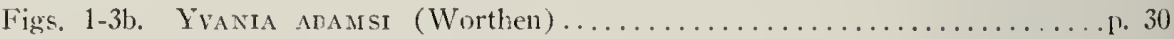
Specimens from Peoria County.

Figs 4a-5c. Yvinia subconstricta (Meek and Worthen).................. 32 4a-5c. Specimens from Peoria County.

4b. Upper surface of whorl ( $x 8)$.

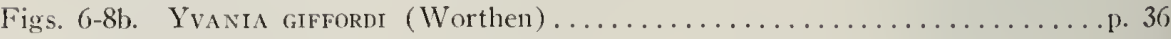
Specimens from Peoria County.

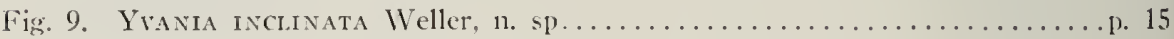
Holotype. Upper surface of whorl ( $x$ 8). 

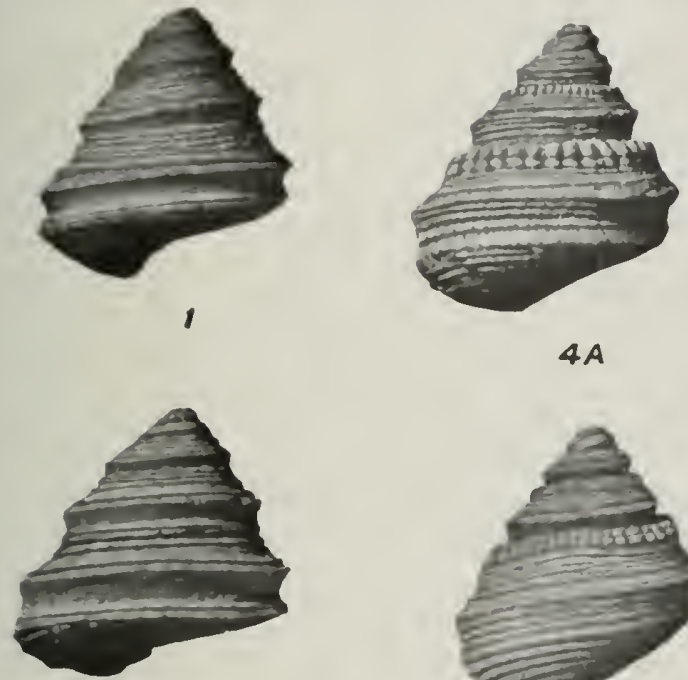

2
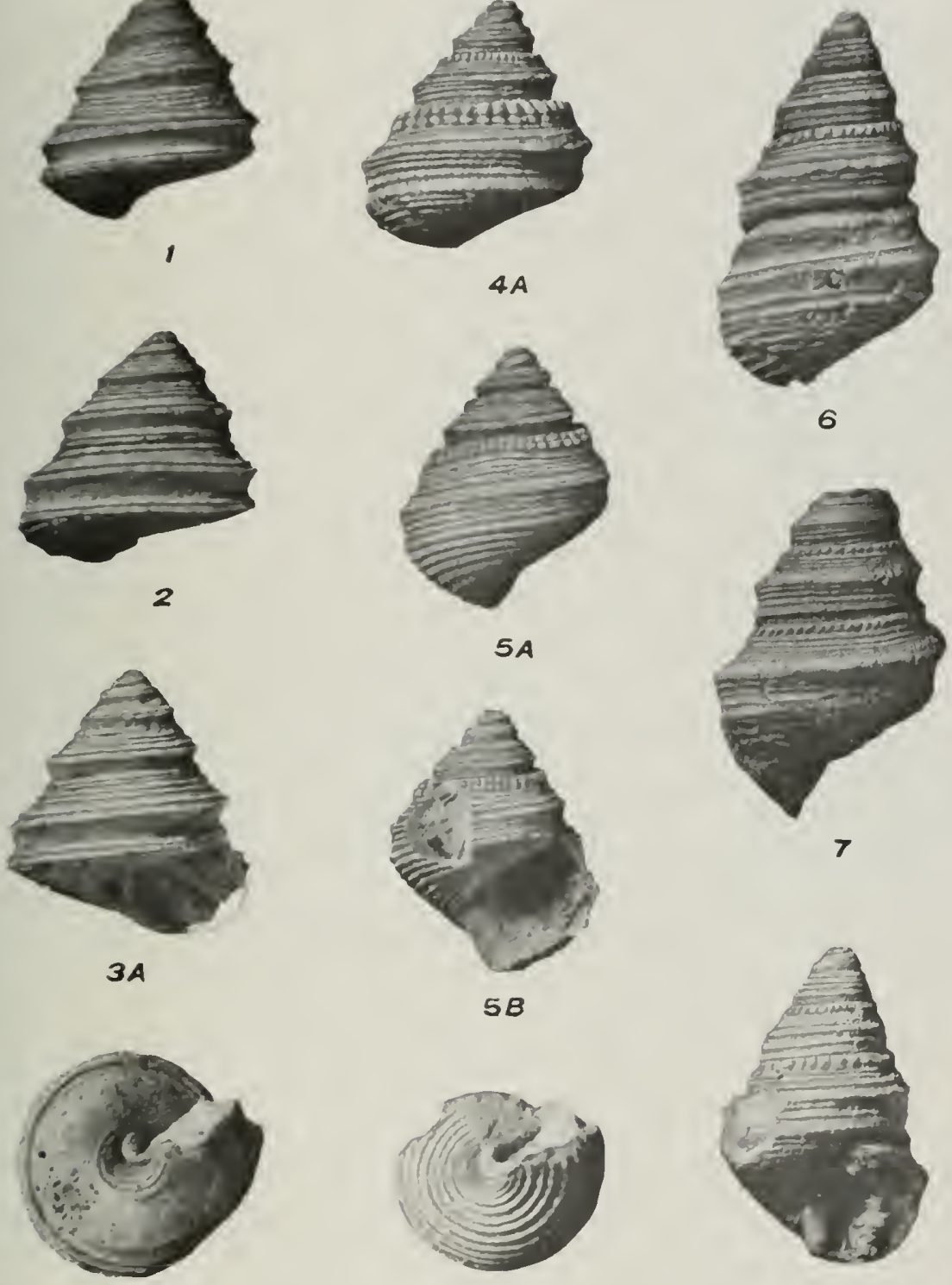

$3 B$
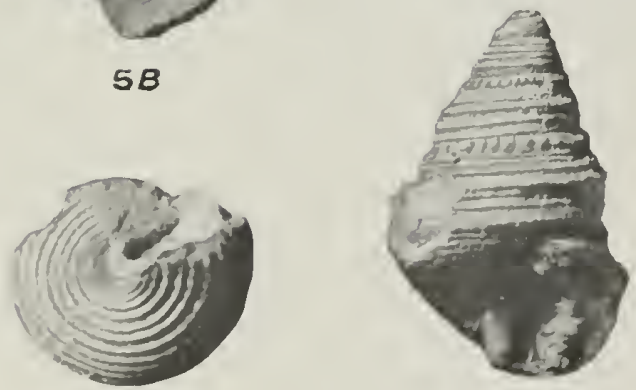

50

\section{4}

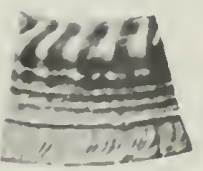

$4 B$

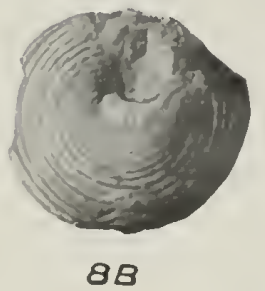




\section{EXPIANATION OF PLATE III}

Figures la to 5 are cnlarged four diamcters except 1d which is enlarged eight diameters.

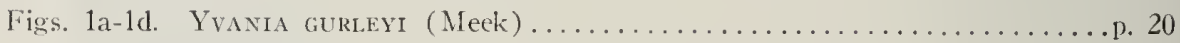
la-d. The holotype.

1d. Innmature portion of the spire showing devclopment $(\times 8)$.

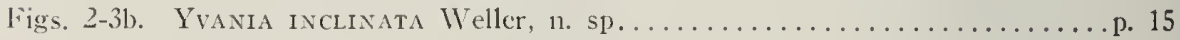
2. A paratype.

3a-b. The holotype.

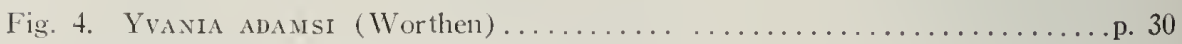
Internal cast from Peoria County.

Fig. 5. Yvinia giffordi (Worthen) ............................... 36 Internal cast from Pcoria County.

The following curves indicate in a diagrammatic fashion the form of the apertures of scveral of the species described. The whorl is to be considered as flattened out with the suture above and the columella or umbilicus below. The horizontal mark midway on the curves indicates the position of the angulation separating the lateral and basal surfaces. It is to be noted that the apertures are broken away in all specimens observed and therefore the depth of the slit is unknown. It probably does not exceed one eighth of a turn. The relations of the aperture above and below the slit are also uncertain. The curves presented herewith have becn drawn from growth lines which left the slit band opposite each other, although it is possible that the aperture was actually more advanced upon one side than upon the other.

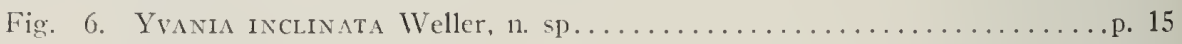

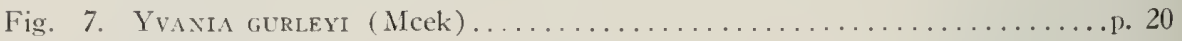

Fig. 8. Yvania supercrexata Veller, n. sp......................... 22

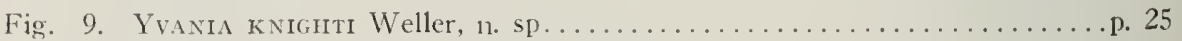

Fig. 10. Yvania subconstricta (Meck and IVorthen) .................... 32

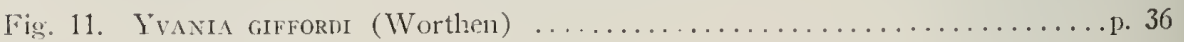






\section{CHILIS: \\ LIBEARY BDIUEFS}

502 S. Goodirte Urbara III

\section{$4-$}


